\title{
Data Recovery Efforts at the Millville Mill Site (41RK223), Rusk County, Texas
}

Eugene R. Foster Jr.

Unknown

Wayne Glander

Follow this and additional works at: https://scholarworks.sfasu.edu/ita

Part of the American Material Culture Commons, Archaeological Anthropology Commons, Environmental Studies Commons, Other American Studies Commons, Other Arts and Humanities Commons, Other History of Art, Architecture, and Archaeology Commons, and the United States History Commons

Tell us how this article helped you.

This Article is brought to you for free and open access by the Center for Regional Heritage Research at SFA ScholarWorks. It has been accepted for inclusion in Index of Texas Archaeology: Open Access Gray Literature from the Lone Star State by an authorized editor of SFA ScholarWorks. For more information, please contact cdsscholarworks@sfasu.edu. 


\section{Data Recovery Efforts at the Millville Mill Site (41RK223), Rusk County, Texas \\ Creative Commons License \\ (c) (1) (9)}

This work is licensed under a Creative Commons Attribution-NonCommercial 4.0 International License 


\section{Data Recovery Efforts at the Millville Mill Site (41RK223), Rusk County, Texas}

Eugene R. Foster, Jr. and Wayne Glander

In September 1993, data recovery efforts were undertaken by Espey, Huston \& Associates, Inc. (EH\&A) of Austin, Texas, to mitigate the effects of lignite mining on site 41RK223 in Texas Utilities Mining Company's Oak Hill/2280 Acre Mine permit area of north-central Rusk County, Texas. The data recovery efforts were planned and conducted in coordination with the Department of Antiquities Protection at the Texas Historical Commission (THC) and Mr. Matthew Tanner of TU Services. The site was originally recorded by EH\&A during a 1989 survey of the Oak Hill/2280 Acre Mine permit area based on information received from local informants, Orville Todd and Herman Ballow. Both men recalled swimming as children in the vicinity of an old framework of heavy timbers submerged within Boggy Branch, a tributary to Mill Creek. Local history accounts suggested that the timbers were likely the remains of one of several old water-powered mills historically associated with the Mill Creek floodplain.

Oral interviews and archival research conducted with the assistance of Ms. Susan Weaver of the Railroad Depot Historical Museum in nearby Henderson, Texas, suggested that the site was likely associated with the ghost-town of Millville which had thrived between about 1850 and the late 1870s. The town of Millville in that period was a regionally important economic and educational center located along a principal stage and telegraph route linking Shreveport, Jefferson, Marshall, Millville, and Henderson. By virtue of its excellent agricultural potential and growing economic and social prosperity, the Rusk County area had been densely settled by Anglo-American planters as early as the 1830s and continued to attract settlers and entrepreneurs into the Antebellum and Reconstruction periods. It is notable that several of Millville's most prominent citizens came from the nearby port town of Camden, Texas, on the Sabine River, where Jesse Walling had operated a ferry crossing and Enoch Hays and Willis Calloway both operated successful businesses. Although a community may have existed in the Boggy Branch vicinity as early as the $1830 \mathrm{~s}$, the town had its official beginnings when Walling, a veteran of the Battle of San Jacinto and long associated with the early history of Rusk County, provided four acres of land for the establishment of the Liberty Hill school or church and cemetery. The four acre tract that Walling provided is the same as that of the current Millville Baptist Church and cemetery.

At the apex of its development and social influence, the town of Liberty Hill (Millville) included a number of local industries, businesses, social organizations, a 
renowned hotel (site 41RK63A), as well as the state-chartered Millville Male and Female Academy. Central to its function as a regional market center was the Hays and Calloway grist mill and cotton gin, which reputedly served as the town's namesake after ca. 1850 . Local accounts suggest that the mill was built about that time by Tennessee millwright Benjamin Wilhelm, who also developed a number of other craft-related industries and businesses in the town. Although the loss of early Rusk County deed records precludes verification of the mill's location within the Millville vicinity, the mill's reported location approximately 0.5 miles west on Boggy Branch corresponds very closely to that of 41RK223. The mill continued to operate well into, and possibly beyond, the Reconstruction period, but the town's social and economic importance declined following Reconstruction when the railroad bypassed the town in favor of nearby Henderson. Millville's viability as a community further declined in the post-railroad era as the construction of the modern highway system also bypassed the town in the early twentieth century and the local polling place was moved to nearby Oak Hill.

Upon first examination, site 41RK223 appeared to consist solely of a very low earthen berm that intersected the north bank of Boggy Branch. Following EH\&A's shovel testing and remote magnetic sensing surveys of the area including and surrounding the reported location of the mill site, a large wooden timber approximately $9.1 \mathrm{~m}$ in length (30 feet) was located, as reported, submerged within the channel of Boggy Branch. Through additional coordination with the THC and the Railroad Commission of Texas, mechanical trenching was used to divert the waters of Boggy Branch around the site and expose a partially buried timber framework. Upon examination by EH\&A's architectural preservation specialist, the framework was noted to exhibit typical nineteenth century mill construction methods and materials. Dendrochronological sampling and analysis was then applied to refine the estimated mid-nineteenth century construction date.

To reveal the extent of the structural remains and answer questions concerning the structure's age and configuration, a data recovery program was developed which included the mechanical removal of approximately $1.5 \mathrm{~m}$ of alluvial overburden as well as additional dendrochronological analysis and archival research. The mechanical excavation revealed that the structural configuration was largely limited to the rectangular framework of timbers exposed in the previous testing effort, with the upstream end member extending laterally into the south creek bank, presumably serving as an anchor for the entire structure (Figure 1). 


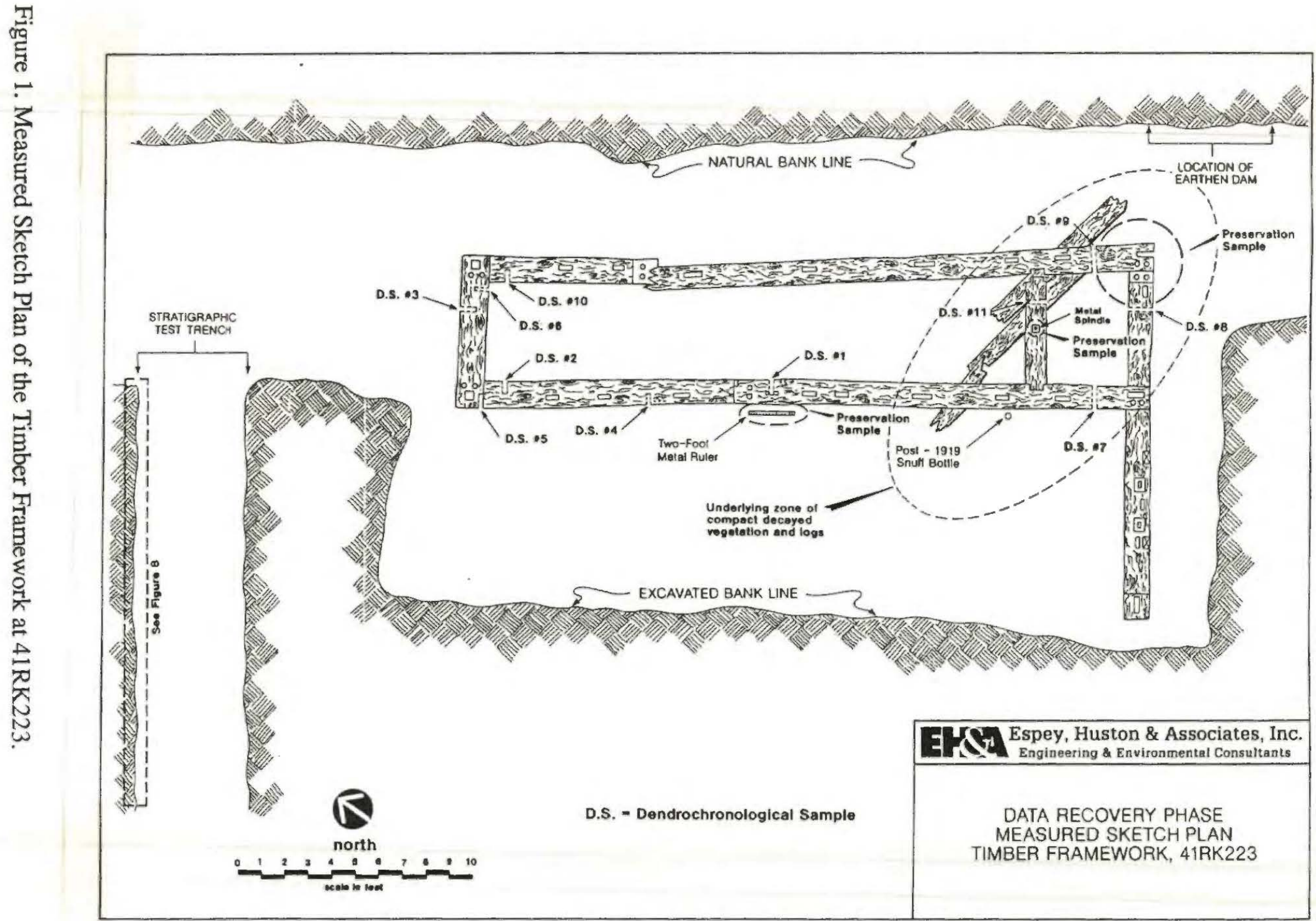

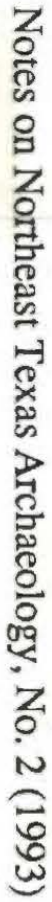


More careful hand excavation and cleaning permitted detailed documentation and analysis of the structural elements and the underlying soil matrix. Special samples of the timbers were carefully selected for further dendrochronological sampling and permanent curation. The dendrochronological analysis revealed a very closely correlated set of cutting dates ranging around the year 1853, somewhat later than some accounts suggest for the construction of the Hays and Calloway mill. Observations of the stream bed matrix beneath the framework exposed a layer of blackened, decayed leaf matter, and several intact natural logs oriented diagonally across the existing creek channel, suggesting that the creek channel had probably been artificially straightened to facilitate water flow along the length of the structure. This interpretation was further supported by examination of a mechanically excavated trench that showed former bankline and streambed deposits extending well into the south bank.

Architecturally, a variety of wood types were used in the structure, possibly according to their particular location and function within the structure, with white oak being the most prevalent. The individual timbers were all hand-hewn, approximately $11 \times 11$ inches in cross-sectional dimension, and were joined at the corners and along the two long "main beam" sides by double-pegged, half-lap joints. A number of mortise pockets occurred in pairs along the length of the two main beams, with the center-most pairs being substantially larger than the others. It was estimated that these center-most pairs of mortise pockets could have supported a vertical framework that could, in turn, have supported a horizontally shafted water wheel useful for powering adjacent grist milling, saw milling, and cotton ginning/pressing operations.

The presence of a series of mortises in the lateral member buried in the south creek bank and forming the upstream end of the framework could not be adequately explained, although the remnants of two vertical posts were observed to have undergone severe stresses which left only a small portion of each still inserted into the lateral beam. The preservation of these two elements is likely due to their burial within the south creek bank. The edges of the lateral beam in this vicinity were better preserved than those edges and surfaces which had apparently been exposed and eroded within the creek channel. While the other mortises along that beam may have supported additional wooden or metal columns, the only metal element of the framework was a conical spindle of cast metal set into an internal cross-member (see Figure 1). This interesting element may have served as a pivot point for a water-control gate at the head of the framework. This element was also collected for conservation by Texas A\&M University.

Although local history accounts provide somewhat contradictory information concerning the history of the Hays and Calloway mill, and essential primary source records 
appear to have been irretrievably lost as a result of two courthouse fires in Rusk County, the data recovered from 41RK223 clearly suggests that it is the Hays and Calloway mill around which the town of Millville thrived in the mid-to-late nineteenth century. While such water-powered mills have played an important part in western civilization since ancient Roman times and were vital elements in the settlement and development of most Northeast Texas agricultural communities, they have truly become part of Northeast Texas' lost material culture. Their disappearance is due in part to the nature of their construction, as well as the eventual invention of industrial roller mills that virtually displaced the ancient stone "buhr-wheel" mills used for grinding corn and wheat into meal and flour.

To date only a few such water-powered mill sites have been identified and investigated archaeologically in the Northeast Texas region. Among these, site 41RK223 is important not only for its rarity, but also for its unique status as the only known Northeast Texas archeological site at which dendrochronology has been applied. The results of the dendrochronological sampling and analysis not only yielded the desired information for refining the estimated date of construction for the site, but provided important information required to improve the regional dendrochronological data base for Northeast Texas. 